\title{
Review
}

\section{Physical activity and exercise on diabetic foot related outcomes: A systematic review}

International

Diabetes

Federation

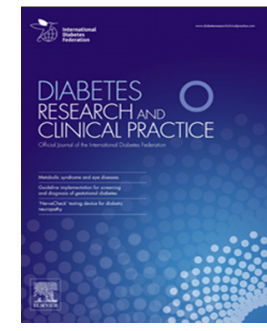

\author{
Monica Matos ${ }^{a, *}$, Romeu Mendes ${ }^{b, c, d}$, André B. Silva ${ }^{e}$, Nelson Sousa ${ }^{a, b}$ \\ ${ }^{a}$ Research Center in Sports Sciences, Health Sciences and Human Development, Vila Real, Portugal \\ ${ }^{\mathrm{b}}$ University of Trás-os-Montes e Alto Douro, Vila Real, Portugal \\ ${ }^{c}$ Public Health Unit, ACES Douro I - Marão e Douro Norte, Vila Real, Portugal \\ d EPIUnit - Instituto de Saúde Pública, Universidade do Porto, Porto, Portugal \\ ${ }^{\text {e } C e n t r o ~ H o s p i t a l a r ~ T o n d e l a ~ V i s e u, ~ O p h t h a l m o l o g y ~ D e p a r t m e n t, ~ V i s e u, ~ P o r t u g a l ~}$
}

\section{A R T I C L E I N F O}

Article history:

Received 17 October 2017

Received in revised form

1 February 2018

Accepted 13 February 2018

Available online 23 February 2018

Keywords:

Physical activity

Exercise

Diabetic foot

Diabetes

\begin{abstract}
A B S T R A C T
Background: Diabetic foot is one of the most common complications of diabetes. It has the potential risk of pathologic consequences including infection, ulceration and amputation, but a growing body of evidence suggests that physical activity and exercise may improve diabetic foot outcomes.

Objective: To analyze de effects of exercise and physical activity interventions on diabetic foot outcomes.

Methods: A comprehensive and systematic search was conducted according to PRISMA recommendations. Only controlled clinical trials with patients with diabetes were included. Results: Six studies, involving 418 patients with diabetes, were included. Two studies used only aerobic exercise; two studies combined aerobic, resistance and balance exercise; and two studies combined aerobic and balance exercise by Thai Chin Chuan methods. Physical activity and exercise significantly improved nerve velocity conduction, peripheral sensory function and foot peak pressure distribution. Moreover, the ulcers incidence rate per year was lower in the intervention groups, compared with the controls [0.02 vs. 0.12].

Conclusion: This review suggests evidence that physical activity and exercise is an effective non-pharmacological intervention to improve diabetic foot related outcomes. Combined multi-disciplinary treatments are more effective in the prevention of foot complications in patients with diabetes.
\end{abstract}

(c) 2018 Elsevier B.V. All rights reserved.

\footnotetext{
* Corresponding author at: CIDESD, Universidade de Trás-os-Montes e Alto Douro, Parque Desportivo da UTAD, 5000-801 Vila Real, Portugal.

E-mail addresses: m.s.matos8@gmail.com (M. Matos), romeuduartemendes@gmail.com (R. Mendes), andreborgessilva@outlook.com (A.B. Silva), nelsons@utad.pt (N. Sousa). 


\section{Contents}

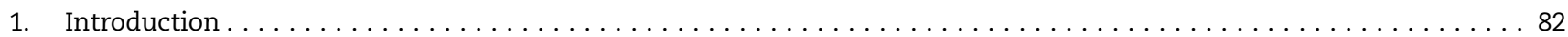

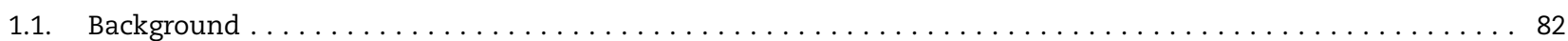

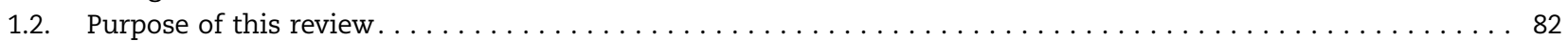

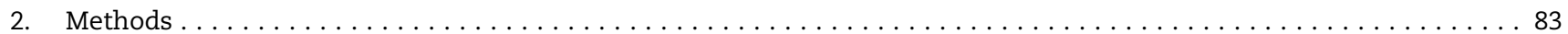

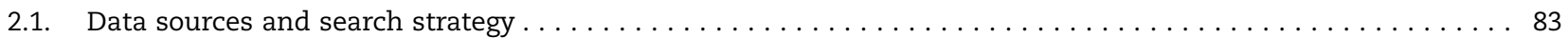

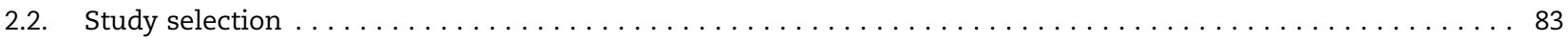

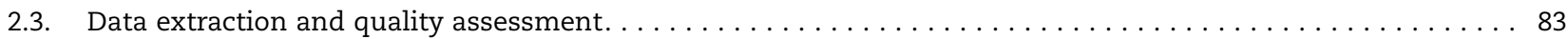

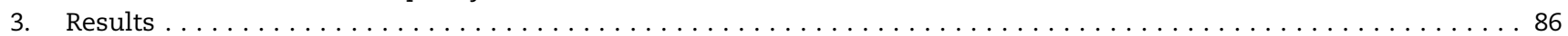

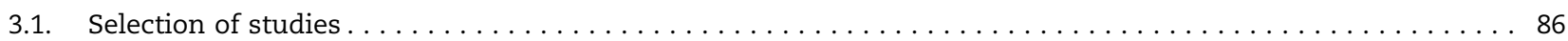

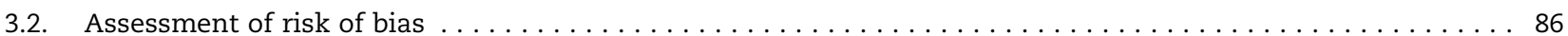

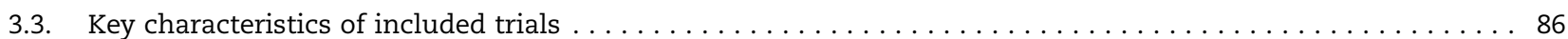

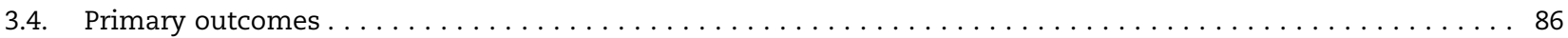

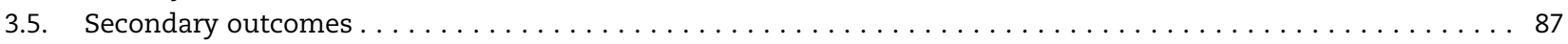

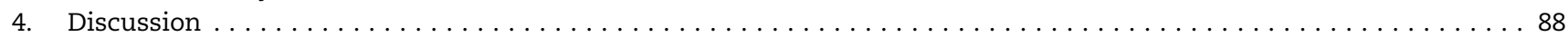

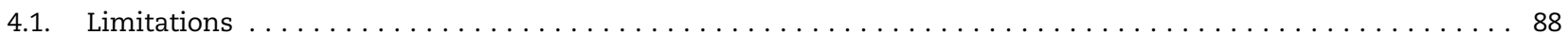

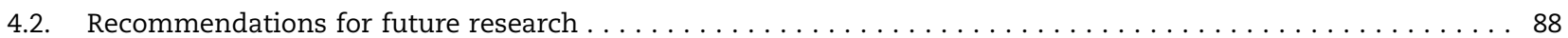

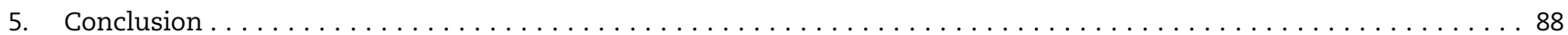

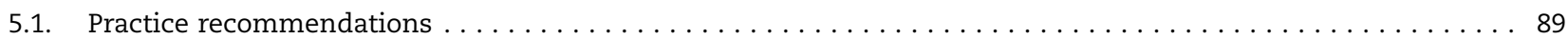

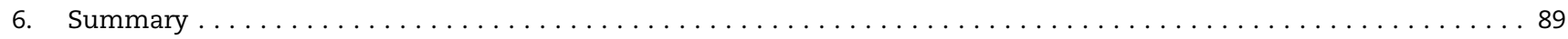

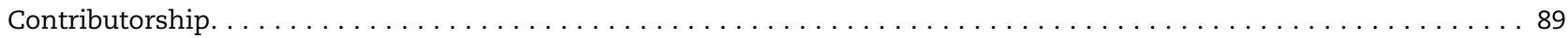

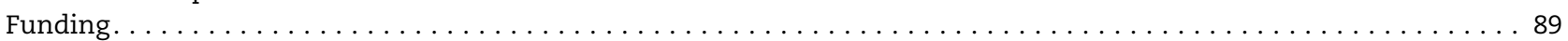

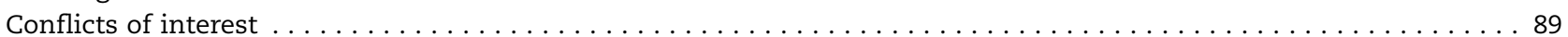

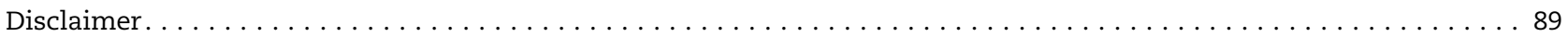

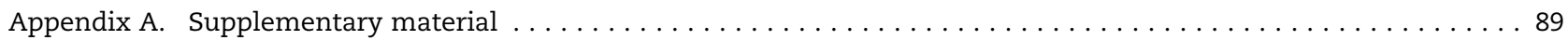

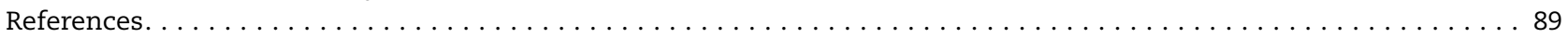

\section{Introduction}

\subsection{Background}

Diabetic foot ulcer is defined as a full-thickness wound that destroys the deep tissues and develops at a level distal to the ankle and is associated with neurological abnormalities in patients with diabetes [1-3] These ulcers can be classified as neuropathic, ischemic or neuro-ischemic [4-6]. The neuropathic, commonly occur on the plantar surface of the metatarsal heads, or in areas overlying a bone deformity and is usually induced by foot deformity and high foot pressures, provoking tissue damage. Once the tissue breakdown, the resultant ulceration becomes chronic as the insensate foot fails to convey nociceptive stimuli which are necessary to provoke protective behavior [7-9] as a consequence of nerve damage, affecting peripheral sensation and fine vasomotor control of the pedal circulation $[1,10,11]$. Ischemic ulceration can be represented as an absence of foot pulses, mainly because of macrovascular or microvascular disease [12,13] causing a hard healing of the wound, result of an inadequate vascular perfusion in the lower limb [14,15] and frequently occurs on the tips of the toes or on the lateral border of the foot $[16,17]$. The neuro-ischemic ulceration has both neuropathic and ischemic and it develops on the margins of the foot and toes usually from the pressure of poorly fitted shoes [18]. Foot ulcer precedes the major of amputations in patients with diabetes by $80 \%$. Foot ulcers, with or without signs of infections, and amputations are major causes of morbidity [19-23] and disability in these patients, leading to significantly lower daily activity $[24,25]$ and is even correlated with a higher risk of death $[20,21,23,26]$. The management of ulcers and their prevention is important to ensure quality of life and decrease comorbidities and death [19].

\subsection{Purpose of this review}

There is an establish evidence of a positive association between exercise and diabetes, particularly by improving glycemic control, and insulin sensitivity in individuals with type 2 diabetes, along with positive effects on lipids, blood pressure, cardiovascular events, mortality, and quality of life $[27,28]$. However, less is known about the effects of physical activity and exercise in diabetic foot outcomes. Recent studies have suggested that physical activity and exercise may improve the distribution of dynamic plantar loading, nerve velocity conduction and foot mobility function, reflecting a better involvement of the whole foot during walking process $[29,30]$ and decreasing the incidence of foot ulcer or lesion [31-33].

Therefore, the purpose of this systematic review was to analyze the effects of exercise and physical activity interventions on diabetic foot outcomes. 


\section{Methods}

This systematic review was conducted in accordance with the Preferred Reporting Items for Systematic Review and MetaAnalyses (PRISMA) guidelines.

\subsection{Data sources and search strategy}

Comprehensive and systematic searches were conducted in February 2017 by two independent authors [MM and NS] using the following electronic databases and a combination of medical subject headings and keywords: PubMed; The Cochrane Online Library; Web of Science and Scopus. The following keywords were used: ((feet OR foot) [title] AND (diabetes OR
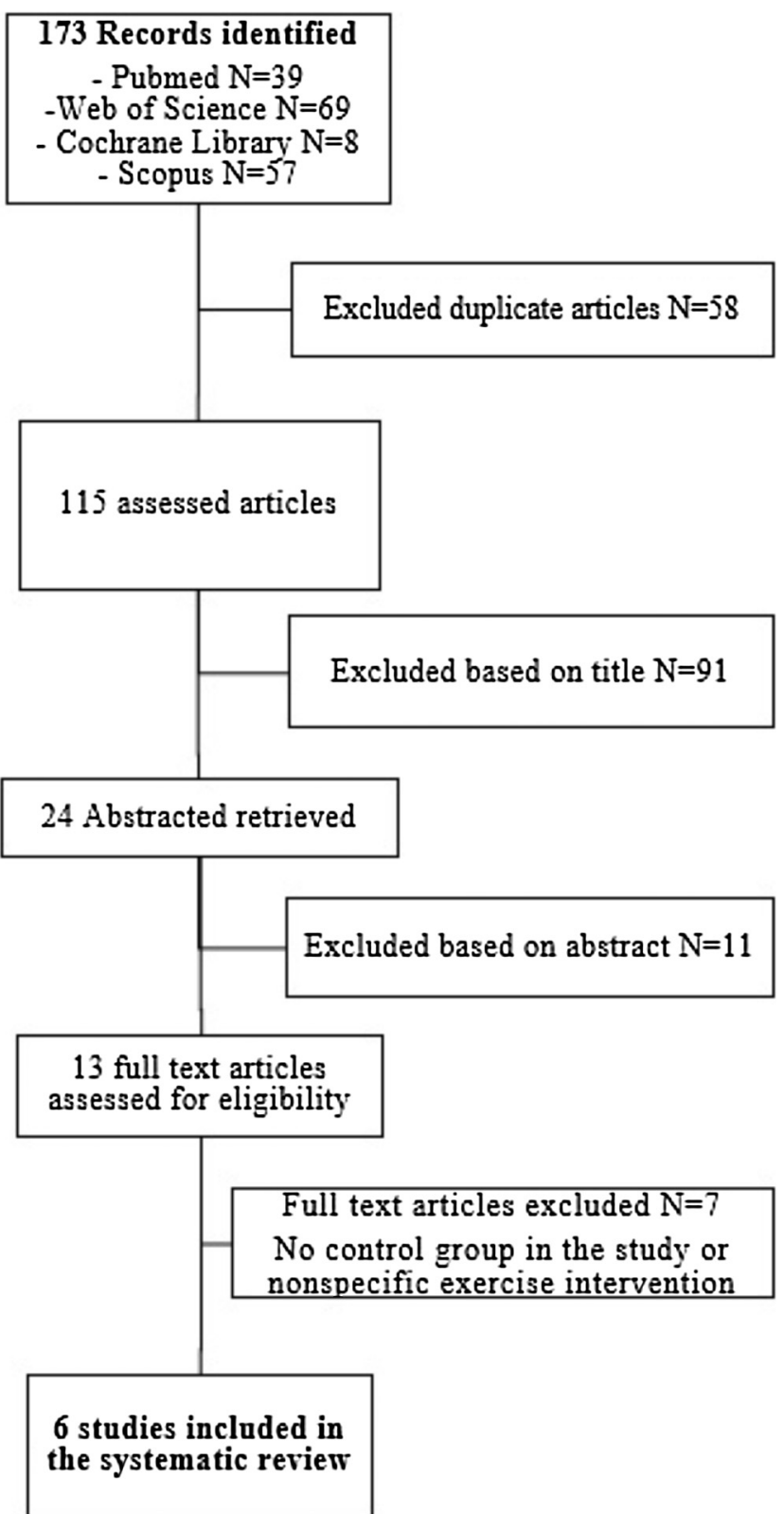

Fig. 1 - Flow diagram of the included studies. diabetic OR neuropathy OR ulcer ) [title] AND ("physical activity" OR exercise OR training OR walking OR jogging OR cycling OR running OR swimming OR pilates OR yoga OR rowing OR climbing) [title]). Electronic databases were searched from the beginning until July 2017.

\subsection{Study selection}

Two authors [MM and NS] independently screened the title and abstract of every citation found in our literature search. Studies of potential relevance were the target of a search for the full text version, and eligibility criteria were applied. According to PRISMA recommendations, inclusion and exclusion criteria are based on relevant study characteristics (participants, intervention, comparator, outcome, study design). Studies were included if: (i) the population was composed by patients with a diagnosis of diabetes regardless of etiology, or a clinical diagnosis of diabetic peripheral neuropathy, polyneuropathy or diabetic foot ulcer; (ii) the intervention was any form of supervised physical activity at a care center or at home; (iii) the comparator was daily-life physical activity (absence of supervised physical activity or exercise regimen) and/or usual foot care education.

Non-human articles were excluded from this systematic review as well as studies lacking original data (e.g. letters, review articles or editorials), articles on unrelated topics, studies not reporting outcome of interest and studies containing < 10 participants. In addition, clinical trials with no control group were also excluded as well as clinical trials with nonspecific exercise intervention.

\subsection{Data extraction and quality assessment}

Eligible studies were examined independently by two collaborators [MM and NS], and any disagreement was settled via discussion among the authors. The study features extracted from each paper include: first author, year of publication, predisposing factor, number of participants in the intervention and control groups, mean or range age of participants, duration of intervention, a description of the intervention and control groups, primary and secondary outcomes, and main results. A meta-analysis was deemed unfeasible because of the small number of studies and heterogeneous outcome measures.

Risk of bias was assessed independently by two researchers [MM and NS], who were blinded to each others' quality assessment. All studies were scored using the PEDro critical appraisal tool for experimental studies.

PEDro is a reliable tool consisting of 11 items [34]. Item 1 is related to external validity and is not used in the scoring, as described in the PEDro guidelines. Each criterion can be answered with 'yes' or 'no'. 'Yes' was rated with 1 point, 'no' with 0 points. The possible maximum score is 10 points. Studies with a total PEDro score of at least 5 points were considered to have low risk of bias. Disagreement between the reviewers regarding the quality score of an article was discussed until consensus was reached. If necessary, a third opinion was sought $[\mathrm{RM}]$. 
Table 1 - Characteristics of the included studies.

\begin{tabular}{|c|c|c|c|c|c|c|c|c|}
\hline $\begin{array}{l}\text { Authors/study } \\
\text { design }\end{array}$ & $\begin{array}{l}\text { Participants }(\mathrm{N}) \text { and } \\
\text { mean age (years } \pm \\
\mathrm{SD} \text { ) }\end{array}$ & Predisposing factor & Primary outcomes & Secondary outcomes & Intervention group & Control group & Intervention-duration & Results \\
\hline $\begin{array}{l}\text { Balducci et al. [32] } \\
\text { Randomized con- } \\
\text { trolled trial }\end{array}$ & $\begin{array}{l}\text { IG: } N=31 ; \\
49 \pm 15.5 y \\
\text { CG: }=47 \\
52.9 \pm 13.4 \mathrm{y}\end{array}$ & $\begin{array}{l}\text { Diabetic patients } \\
\text { type } 1 \text { or } 2 \text { without } \\
\text { symptoms of DPN }\end{array}$ & $\begin{array}{l}\text { NCV, DL and NAPA } \\
\text { for: PMN and sural } \\
\text { SSN } \\
\text { VPT at malleolus } \\
\text { and hallux }\end{array}$ & $\begin{array}{l}\text { Blood pressure } \\
\text { BMI } \\
\text { FBG } \\
\text { FFM } \\
\text { \%FM } \\
\text { HbA1c } \\
\text { Lipid profile } \\
\text { Microalbuminuria } \\
\text { MLTPA } \\
\text { Waist circumference }\end{array}$ & $\begin{array}{l}\text { Supervised aerobic } \\
\text { exercises (treadmill) } \\
50-85 \% \text { of the heart } \\
\text { rate reserve }\end{array}$ & $\begin{array}{l}\text { Did not perform } \\
\text { supervised physical } \\
\text { activity }\end{array}$ & $\begin{array}{l}4 \text { years } \\
4 \mathrm{~h} \text { weekly }\end{array}$ & 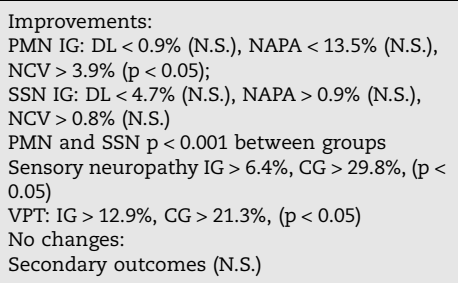 \\
\hline $\begin{array}{l}\text { LeMaster et al. [31] } \\
\text { Randomized con- } \\
\text { trolled trial }\end{array}$ & $\begin{array}{l}\text { IG: } \mathrm{N}=41 ; \\
66.6 \pm 10.4 \mathrm{y} \\
\text { CG: } \mathrm{N}=38 \\
64.8 \pm 9.4 \mathrm{y}\end{array}$ & $\begin{array}{l}\text { Diabetic patients } \\
\text { type } 1 \text { or } 2 \text { with PN }\end{array}$ & $\begin{array}{l}\text { Foot lesions/ulcers } \\
\text { were photographed } \\
\text { and examined } \\
\text { IR }\end{array}$ & $\begin{array}{l}\text { Daily steps at baseline } \\
\text { and at } 3,6,12 \text { months by } \\
\text { ankle accelerometers for } \\
14 \text { days (TDS, S30-min } \\
\text { and WWBA) } \\
\text { Ambulatory minutes per } \\
\text { week } \\
\text { 6MWT }\end{array}$ & $\begin{array}{l}\text { From } 1 \text { to } 3 \text { months - } \\
\text { performed } 3 \text { at- } \\
\text { home sessions with } \\
\text { therapist, weekly for } \\
1 \mathrm{~h} \text { (lower-extremity } \\
\text { muscles } \\
\text { strengthening and } \\
\text { balance exercises) } \\
\text { From } 1 \text { to } 12 \text { months } \\
- \text { self-monitored } \\
\text { walking program } \\
\text { and motivational } \\
\text { telephone calls } \\
\text { every } 2 \text { weeks } \\
+ \\
\text { diabetic foot care } \\
\text { education, regular } \\
\text { foot care }\end{array}$ & $\begin{array}{l}\text { From } 1 \text { to } 3 \text { months - } \\
8 \text { therapist session } \\
\text { at-home only to } \\
\text { examine feet } \\
\text { From } 1 \text { to } 12 \text { months } \\
\text { - diabetic foot care } \\
\text { education, regular } \\
\text { foot care. }\end{array}$ & 12 months & 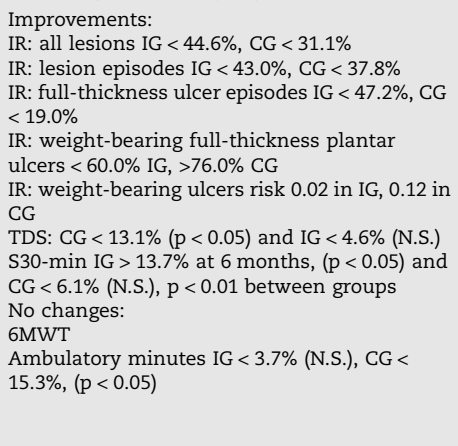 \\
\hline $\begin{array}{l}\text { Hung et al. [36] } \\
\text { Controlled clinical } \\
\text { trial }\end{array}$ & $\begin{array}{l}\text { IG: } N=28 ; \\
58.1 \pm 13.4 y \\
\text { CG: } N=32 ; \\
56.6 \pm 13.3 y\end{array}$ & $\begin{array}{l}\text { IG: Diabetic patients } \\
\text { type } 2(6 \text { with } \\
\text { neuropathy) } \\
\text { CG: healthy adults }\end{array}$ & $\begin{array}{l}\text { NCV of bilateral } \\
\text { motor: median, } \\
\text { ulnar, peroneal, and } \\
\text { tibial nerves } \\
\text { NCV of bilateral } \\
\text { sensory: median and } \\
\text { unnar } \\
\text { DL bilateral: motor } \\
\text { median, ulnar, } \\
\text { peroneal and tibial. } \\
\text { DL for sensory: } \\
\text { median and ulnar } \\
\text { Proximal amplitude } \\
\text { of the motor/ } \\
\text { sensory response }\end{array}$ & $\begin{array}{l}\text { FBG } \\
\text { IRI }\end{array}$ & $\begin{array}{l}\text { Tai Chi Chuan } \\
\text { exercises } \\
\text { Light to moderate } \\
\text { intensity }\end{array}$ & No exercise & $\begin{array}{l}12 \text { weeks } \\
3 \text { times weekly } \\
1 \mathrm{~h} \text { session }\end{array}$ & 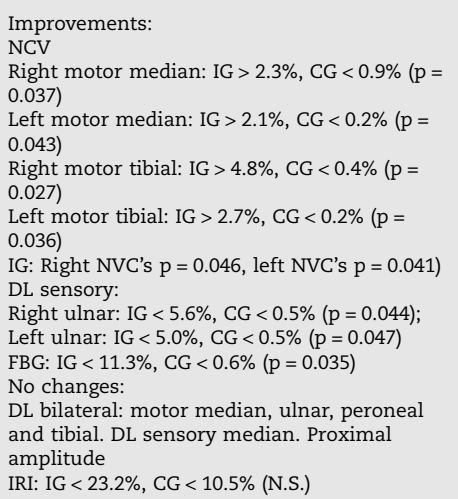 \\
\hline $\begin{array}{l}\text { Ahn \& Song [35] } \\
\text { Quasi-experimental } \\
\text { study }\end{array}$ & $\begin{array}{l}\text { IG: } \mathrm{N}=30 \text {; } \\
66.05 \pm 6.42 \mathrm{y} \\
\text { CG: } \mathrm{N}=29 ; \\
62.73 \pm 7.53 \mathrm{y}\end{array}$ & $\begin{array}{l}\text { Diabetic patients } \\
\text { type } 2 \text { with } \\
\text { neuropathy }\end{array}$ & $\begin{array}{l}\text { SWME } \\
\text { TSS }\end{array}$ & $\begin{array}{l}\text { FBG } \\
\text { HbA1c } \\
\text { Single-leg stance } \\
\text { Quality of life (Korean SF- } \\
\text { 36v2) }\end{array}$ & $\begin{array}{l}\text { Tai Chi Chuan } \\
\text { exercises } \\
\text { Low-to-moderate } \\
\text { intensity } \\
+ \\
\text { routine education } \\
\text { on diabetes, diet, } \\
\text { exercise, foot care, } \\
\text { and medication } \\
\text { twice during study } \\
\text { period } \\
\text { Dropout } \mathrm{N}=10\end{array}$ & $\begin{array}{l}\text { Routine education } \\
\text { on diabetes, diet, } \\
\text { exercise, foot care, } \\
\text { and medication } \\
\text { twice during study } \\
\text { period } \\
\text { Dropout } \mathrm{N}=10\end{array}$ & $\begin{array}{l}12 \text { weeks } \\
\text { twice weekly } \\
1 \mathrm{~h} \text { session } \\
3 \text { months follow-up }\end{array}$ & $\begin{array}{l}\text { Improvements: } \\
\text { SWME: IG }<2.6 \%, C G<6.1 \%(p=0.535) \\
\text { TSS: improvements for IG }(19.5 \%),(p=0.042) \\
\text { compared CG } \\
\text { FBG: IG }<9.0 \%, C G>8.3 \%(p=0.036) \\
\text { HbA1c: IG }<6.0 \%, C G>3.7 \%(p=0.004) \\
\text { Single leg stance: IG }>34.2 \%, C G<9.2 \%(p= \\
\text {.044) } \\
\text { Korean SF- } 36 \text { IG: physical functioning }>7.0 \% \text {, } \\
\text { bodily pain }>17.6 \% \text {, physical role limitation }> \\
29.0 \% \text {, emotional role limitation }>30.3 \% \text {, social } \\
\text { functioning }>15.6 \%\end{array}$ \\
\hline
\end{tabular}




\section{Table 1 - (continued)}

\begin{tabular}{|c|c|c|c|c|c|c|c|c|}
\hline $\begin{array}{l}\text { Authors/study } \\
\text { design }\end{array}$ & $\begin{array}{l}\text { Participants }(\mathrm{N}) \text { and } \\
\text { mean age (years } \pm \\
\text { SD) }\end{array}$ & Predisposing factor & Primary outcomes & Secondary outcomes & Intervention group & Control group & Intervention-duration & Results \\
\hline $\begin{array}{l}\text { Dixit et al. [33] } \\
\text { Randomized con- } \\
\text { trolled trial }\end{array}$ & $\begin{array}{l}\text { IG: } \mathrm{N}=40 ; \\
54.40 \pm 1.24 \text { y } \\
\text { CG: } \mathrm{N}=47 \\
59.45 \pm 1.16 \mathrm{y}\end{array}$ & $\begin{array}{l}\text { Diabetic patients } \\
\text { type } 2 \text { with PN }\end{array}$ & $\begin{array}{l}\text { NVC in PMN and } \\
\text { SSN by } \\
\text { Electromyography } \\
\text { MDNS }\end{array}$ & $\begin{array}{l}\text { BMI } \\
\text { Hip circumference } \\
\text { Waist circumference } \\
\text { Waist to hip ratio }\end{array}$ & $\begin{array}{l}\text { Education for foot } \\
\text { care, diabetic diet } \\
\text { and standard } \\
\text { medical care } \\
+ \\
\text { treadmill exercises } \\
\text { (40-60\% heart rate } \\
\text { reserve) moderate } \\
\text { intensity } \\
\text { Dropout } \mathrm{N}=11\end{array}$ & $\begin{array}{l}\text { Education for foot } \\
\text { care, diabetic diet } \\
\text { and standard } \\
\text { medical care } \\
+ \\
\text { Telephone calls } \\
\text { every second week } \\
\text { of the month and } \\
\text { evaluated for } \\
\text { medical care at } 4 \\
\text { and } 8 \text { weeks } \\
\text { Dropout } \mathrm{N}=10\end{array}$ & $\begin{array}{l}8 \text { weeks } \\
3-6 \text { days weekly }\end{array}$ & $\begin{array}{l}\text { Improvements: } \\
\text { NVC } \\
\text { PMN: IG }>7.3 \%, C G<0.5 \%(p=0.03) \\
\text { SSN: IG }>32.6 \%, C G>1.1 \%(p<0.001) \\
\text { MDNS scores IG }<44.1 \%, C G>7.5 \%(p<0.001) \\
\text { No changes: } \\
\text { BMI, hip circumference, waist circumference } \\
\text { and waist to hip ratio }\end{array}$ \\
\hline $\begin{array}{l}\text { Sartor et al. [30] } \\
\text { Randomized } \\
\text { controlled trial }\end{array}$ & $\begin{array}{l}\text { IG: } N=26 ; 59 \pm 4 y \\
\text { CG: } N=29 ; 60 \pm 12 y\end{array}$ & $\begin{array}{l}\text { Diabetic patients } \\
\text { type } 1 \text { or } 2 \text { with } \\
\text { polyneuropathy }\end{array}$ & $\begin{array}{l}\text { MNSI questionnaire } \\
\text { MNSI physical } \\
\text { assessment of feet } \\
\text { PP, TPP, PTI, COP } \\
\text { (heel, midfoot, } \\
\text { medial forefoot, } \\
\text { lateral forefoot, } \\
\text { hallux and toes) }\end{array}$ & $\begin{array}{l}\text { ABC Scale } \\
\text { MF: extensor digitorum } \\
\text { longus and brevis; } \\
\text { extensor halluces longus } \\
\text { and brevis; flexor } \\
\text { digitorum brevis; flexor } \\
\text { hallucis brevis; lumbrical; } \\
\text { interosseous; tibialis } \\
\text { anterior; triceps surae } \\
\text { FT: ankle flexion, ankle } \\
\text { extension, toes flexion, } \\
\text { toes extension } \\
\text { KK: Sagittal ankle range } \\
\text { of motion; sagittal ankle } \\
\text { angle; sagittal peak of } \\
\text { extensor; sagittal peak of } \\
\text { flexor }\end{array}$ & $\begin{array}{l}\text { Physical therapy and } \\
\text { instructions to } \\
\text { exercise at home, for } \\
\text { foot-ankle and gait } \\
\text { ((a) increase foot and } \\
\text { ankle range of } \\
\text { motion, (b) } \\
\text { strengthen foot and } \\
\text { ankle muscles, (c) } \\
\text { increase foot and } \\
\text { ankle performance } \\
\text { through functional } \\
\text { exercises, and (d) } \\
\text { increase walking } \\
\text { skills and foot } \\
\text { rollover training) }\end{array}$ & $\begin{array}{l}\text { Didn't receive any } \\
\text { physical therapy, } \\
\text { instructions or } \\
\text { intervention } \\
\text { Only received } \\
\text { customized medical } \\
\text { care }\end{array}$ & $\begin{array}{l}12 \text { weeks } \\
\text { twice weekly } \\
40-60 \mathrm{~min} / \mathrm{session} \\
\text { Follow-up: IG assessed at } \\
\text { week } 24\end{array}$ & $\begin{array}{l}\text { Improvements: } \\
\text { PP: IG }<23.3 \% \text { midfoot }(p<0.01),<8.8 \% \text { lateral } \\
\text { forefoot }(p<0.01 \text { ) follow-up } \\
\text { TPP: IG }>1.7 \% \text { heel }(p=0.03),<2.1 \% \text { lateral } \\
\text { forefoot }(p=0.01) \text { interaction effects } \\
\text { PTI: } \mathrm{G}>9.3 \% \text { medial forefoot, }>16.7 \% \text { hallux } \\
\text { after } 12 \text { weeks ( } p<0.01) \text {. Interaction effects } \\
\text { midfoot }(p=0.03) \\
\text { COP: IG }<20.0 \% \text { midfoot }(p=0.03) \text {, total foot } \\
\text { area }<25.0 \% \text { ( } p=0.05 \text { ) interaction effect } \\
\text { Total COP IG: follow up } p<0.001 \\
\text { MF: IG }>25.0 \% \text { flexor digitorum brevis, }>25.0 \% \\
\text { tibialis anterior } \\
\text { No changes: } \\
\text { MF: Extensor digitorium longus and brevis, } \\
\text { extensor hallucis longus and brevis, flexor } \\
\text { hallucis brevis, lumbrical, interosseous, triceps } \\
\text { surae } \\
\text { FT, KK, MNSI questionnaire, MNSI physical } \\
\text { assessment, ABC }\end{array}$ \\
\hline $\begin{array}{l}\text { Legend: } A B C \\
\text { peripheral n } \\
\text { and kinema } \\
\text { instrument; } \\
\text { pressure tim } \\
\text { TSS - total s }\end{array}$ & $\begin{array}{l}\text { y; FFM - fat f } \\
\text { S - Michigar } \\
\text { ierve action } \\
\text {; SSN - sural } \\
\text { score; VPT - }\end{array}$ & $\begin{array}{l}\text { ass; FM - fa } \\
\text { tic neurop }\end{array}$ & $\begin{array}{l}\text { FT - functio } \\
\text { ore; MF - m } \\
\text { - non signi } \\
\text { Semmes-We } \\
\text { eshold; WW }\end{array}$ & $\begin{array}{l}\text { st; HbA1c - glyca } \\
\text { function; MLTP } \\
\text { NVC - nerve vel } \\
\text { 10-g monofilam }\end{array}$ & $\begin{array}{l}\text { moglobin; IG } \\
\text { nnesota leisu } \\
\text { onduction; PI }\end{array}$ & peroneal $\mathrm{m}$ & rve; PN - periph & $\begin{array}{l}\text { lcer; DL - distal latency; DPN - diabetic } \\
\text { - insulin resistance index; KK - kinetic } \\
\text { NSI - Michigan neuropathy screening } \\
\text { neuropathy; PP - peak pressure; PTI - } \\
\text { aily steps; TPP - time to peak pressure; } \\
\text { ing blood glucose. }\end{array}$ \\
\hline
\end{tabular}




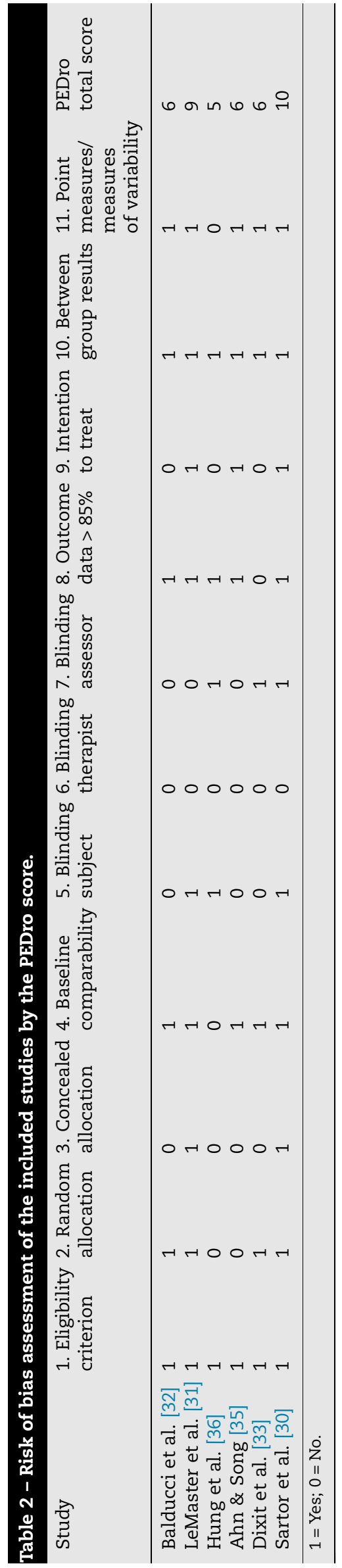

\section{Results}

\subsection{Selection of studies}

We identified a total of 173 articles by our search strategy. From the 173 articles, 58 duplicated references were excluded, remaining 115 articles. In total, 24 articles were assessed for eligibility and a total of 91 articles were excluded based on title. The study selection process and the reasons for exclusion of the articles are shown in Fig. 1. At the end of the research we identified 13 eligible articles but not all of them could be included due to a lack of a control group or due to a nonspecific exercise intervention. Therefore, six clinical trials were included in our systematic review: three studies with type 2 diabetes participants, and three studies with both type 1 and type 2 diabetes participants (see Table 1). There was complete agreement between reviewers regarding study selection.

\subsection{Assessment of risk of bias}

Risk of bias scores for included studies is shown in Table 2. There was total agreement for PEDro scores of all reviewed studies. Two studies had a PEDro score equal to or greater than seven, indicating a high methodological quality; four studies scored between five and seven, indicating a moderate methodological quality. The highest PEDro rating was 10 , with an average of seven among the included studies.

\subsection{Key characteristics of included trials}

A summary of eligible studies is shown in Table 1 . The intervention programs ranged from 8 weeks to 4 years. The articles were published between 2006 and 2014. A total of 418 participants were elected - 196 of which were allocated to the intervention group and 222 to the control group; 41 of these participants dropped out across all studies. The mean age among participants ranged from $49 \pm 15.5$ to $66.6 \pm 10.4$ years. Predisposing factors for the studies were: clinical diagnosis of diabetic neuropathy [31,33,35], with polyneuropathy [30], without symptoms of diabetic peripheral neuropathy [32] and one study only refer six patients with neuropathy due to diabetes mellitus [36].

The treatment approach (exercise) differed among studies: two studies used only aerobic exercise, walking-based [32,33]; two studies combined aerobic exercise walking-based, resistance exercises for the lower limbs muscles, and balance exercise $[30,31]$, and two studies combined aerobic and balance exercise by Thai Chin Chuan methods [35,36]. In addition, some trials used a system of education for foot care plus routine education on diet $[31,33,35,37]$.

\subsection{Primary outcomes}

Nerve velocity conduction was measured in three studies (see Table 1) using a Medelec MS 928 Neurostar electrorecorder [32], a Nicolet Viking IV electrorecorder [36], and the RMS Aleron 201 electromyogram/NCV machine [33]. All three studies found significant improvements in the intervention group, while no differences were detected in the control group. One 
of them reported significant improvements in intervention group in nerve velocity conduction of peroneal motor nerve compared to controls $(p=0.03)$ and the same was observed for sural sensory nerve $(p<0.001)$ after 8 weeks of a supervised walking program [33]. In the other study [32], authors reported significant differences between groups in peroneal motor nerve $(p<0.001)$ and sural sensory nerve $(p<0.001)$ during the four years of study period. Also, authors found a significantly increased in intervention group for peroneal nerve velocity conduction $(p<0.05)$ and a non-significant decreased in controls. For sural there was no significant increase in intervention group. The third study [36] reported significant improvements in nerve velocity conduction after 12 weeks of a Tai Chi Chuan intervention program (right motor nerves $\mathrm{p}=0.046$; and left motor nerves $\mathrm{p}=0.041$ ) while no significant improvements were detected in control group. Authors attribute better results in nerve velocity conduction to bilateral median (right $\mathrm{p}=0.037$; and left $\mathrm{p}=0.043$ ) and tibial (right $\mathrm{p}=0.027$; and left $\mathrm{p}=0.036$ ) reaching a significant improvement after Tai Chi Chuan. The authors of this study also found that exercise decreased distal latency in intervention group by $5.6 \%$ in right sensory ulnar and $5.0 \%$ in left sensory ulnar showing that the interval between the stimulation of a compound muscle and the observed response was faster.

Peripheral sensory function was measured in two studies (see Table 1) through the vibration perception threshold at the Malleolus and Hallux by means of a Biothesiometer [32], and by the Semmes-Weinstein 10-g monofilament examination [35]. One study reported no differences between groups in peripheral sensory function after 12 weeks of a Tai Chi Chuan intervention program, but reported significant improvements (by 19.5\%) in total symptom score for peripheral neuropathy $(p=0.042)$ in the intervention group [35]. Also, the development of vibration perception threshold analyzed in one study was significantly higher in the control group than in the intervention group $(21.3 \%$ vs. $12.9 \%, p<$ $0.05)$, showing greater sensory dysfunction and suggesting that long-term aerobic exercise training can prevent the onset or modify the natural history of diabetic peripheral neuropathy [32].

Two studies controlled the scores of Michigan Neuropathy Screening Instrument (MNSI). Sartor et al. [30] reported no significant differences between groups for the MNSI questionnaire and foot physical examination (Table 1). However, in the experimental group, there was a significant reduction of 2 points in the MNSI questionnaire, which remained after the 12 week follow-up (improvement of 33.3\%), improving the clinical condition of the patients, and a reduction of the score for the physical examination of the feet from 4.5 to 4 points at the follow-up assessment compared to the corresponding scores after 12 weeks (improvement of $11.11 \%$ ) but not significant. In the other study, Dixit et al. [33] reported significant differences in the Michigan Diabetic Neuropathy Score (MDNS) after eight weeks $(p<0.001)$ with a decreased in score by $44.1 \%$ in the intervention group and an increase of $7.5 \%$ for control group.

One study [30] measured peak pressure, time to peak pressure and center of pressure over plantar surface by the Pedar$\mathrm{X}$ System. The authors reported significant reductions in time to peak pressure on heel by $1.7 \%(p=0.03)$ and lateral forefoot by $2.1 \%(p=0.01)$, as well as a significant reduction in peak pressure after follow-up at midfoot $(23.3 \%, \mathrm{p}<0.01)$ and at lateral forefoot $(8.8 \%, p<0.01)$ in the intervention group. The same group also achieved significant differences in center of pressure in midfoot $(20.0 \%$ reduction, $p=0.03)$, and differences in total foot area (25.0\% reduction, $p=0.05)$, at 12 weeks showing a better control of the foot-flattening (see Table 1). Total center of pressure after follow-up had significant differences $(p<0.001)$. After 12 weeks of combined exercise, intervention group increased muscle function in flexor digitorum brevis $(25.0 \%)$ and tibialis anterior $(25.0 \%)$ suggesting that exercise may slow down the prognosis of diabetes chronic complications. All functional tests except ankle extension, showed a difference between groups after 12 weeks, which points to an improvement in intervention group and a worsening in control group.

One study measured the incidence rate of foot lesions by taking photographs of the foot and making an examination of patient's foot [31]. The authors reported that incidence rates of all lesions decreased in intervention group by $44.6 \%$ from 6 months to 12 months and decreased in controls only $31.1 \%$. Also, the incidence rate of weight-bearing fullthickness plantar ulcers decreased in intervention by $60.0 \%$ and increased in controls by $76.0 \%$, showing a risk of $0.02 \mathrm{ul}$ cers/person-year in the intervention group and a risk of 0.1 2 ulcers/person-year in controls. Ulcer rates on plantar weight-bearing areas, total foot ulcer and foot lesions incidence rates did not differ significantly between groups after 6 or 12 months of combined exercise.

\subsection{Secondary outcomes}

Regarding secondary outcomes, statistical significance was reached in fasting blood glucose $(p=0.036$ [35]; $p=0.035$ [36]), and glycated hemoglobin $(p=0.004$ [35]) after the training program in patients with type 2 diabetes compared to controls. Although the insulin resistance index decreased by $23.2 \%$ in intervention group and only $10.5 \%$ in controls, these results were not statistically significant [36].

Regarding functional fitness, the results are inconsistent. In one study [31], there were significant differences between groups (exercise program vs. control) on the number of steps counts per $30-\min (\mathrm{p}<0.01)$, in which the intervention group increased $13.7 \%$ steps counts $(p<0.05)$ whereas the control group decreased $6.1 \%$. However, the authors did not found differences in the 6-min walk test between baseline and six or 12 months. Also, there was no difference between groups in ambulatory physical activity per week from baseline and 6 or 12 months. Balducci et al. [32] also found no differences neither between groups or after four years of aerobic exercises in total physical activity. In other study [34], the performance of single leg stance was significant different between groups ( $\mathrm{p}=0.044)$, as intervention group increased their balance by $34.2 \%$ and controls decreased by $9.2 \%$. Although Sartor et al. [30], found improvements in balance controlled by Activities-specific Balance Confidence (ABC) Scale, reporting an increase of $2.4 \%$ after 12 weeks of exercise intervention and $6.0 \%$ after 24 weeks of follow up, these results were not significant. The same authors found no differences after 12 
weeks in intervention group in muscle function, but the control group worsened in this parameter.

Quality of life was controlled by The Korean SF-36 v2 instrument showed better results in life scores on domains of physical functioning $(7.0 \%, p=0.028)$, bodily pain $(17.6 \%$, $p=0.009)$, physical role limitation $(29.0 \%, p=0.006)$, emotional role limitation $(30.3 \%, p=0.002)$, and social functioning (15.6\%, $p=0.001$ ) in diabetic patients who did the Tai Chi Chuan program [35].

For the remaining clinical outcomes, such as body mass index, waist circumference, waist to hip ratio, fat mass percentage, free fat mass, microalbuminuria, lipid profile and bone densitometry [32] there were no significant changes, but exercise did not cause a deterioration in the assessed parameters.

\section{Discussion}

The main finding of this systematic review is that exercise is a beneficial non-pharmacological treatment in diabetic foot outcomes, particularly in increasing nerve velocity conduction of the lower limbs. Additional benefits can be induced by exercise in patients with diabetes, such as skin sensitivity and intraepidermal nerve fiber density, which can delay the usual course of diabetic peripheral neuropathy and delay skin damage and ulceration.

It is well known that patients with diabetes and neuropathies are associated with low nerve velocity conduction owing to demyelination and loss of large myelinated fibers, and a decrease in nerve action potentials owing to loss of axons [38-41], but the present review showed that aerobic exercise can improve, for example, nerve velocity conduction in peroneal motor nerve by $3.9 \%$ and $0.8 \%$ in sural sensory nerve, also decreasing distal latency by $0.9 \%$ [32]. Moreover, Tai Chi Chuan exercises improved nerve velocity conduction by $2.3 \%$ in right motor median and $2.1 \%$ in left motor median, as well as $4.8 \%$ in right motor tibial and $2.7 \%$ in left motor tibial, reducing overall distal latency by $5 \%$ facing greater gains [36]. However, a combined exercise program with aerobic, foot care education, diabetic diet and standard medical care showed a higher impact, with gains in nerve velocity conduction by $7.3 \%$ in peroneal motor nerve and $32.6 \%$ in sural sensory nerve [33]. Similar intervention with combined training program for lower-extremity muscles strengthening, balance and walking plus diabetic foot care education demonstrated to reduce long-term incidence rate of foot lesions by $44.6 \%$ [31].

Moreover, most of the participants in this review had symptoms of neuropathies but none of them reported pain or reported skin infections during the studies. The majority of participants presented in the studies (Table 1), showed improvements in total symptom score for peripheral neuropathy [35] and vibration perception threshold [32] as well as a better physiological foot rollover which reflects in a better redistribution of plantar pressure [30]. Weight-bearing activities did not increase risk of foot re-ulceration [31]. These findings suggest that exercise may positively enhance peripheral circulation and reduce peak plantar pressures, and therefore reducing diabetic foot ulcer risk and improving diabetic foot outcomes.
In the present review, two studies $[35,36]$ demonstrated an improvement in fasting blood glucose and glycated hemoglobin levels, but these benefits are currently well documented in the literature [28,42-45]. Concerning physical function, the amount of steps taken within this patients after an intervention program, suggests that they are liable to increase exercise performance [31]. Also, patients in a Tai Chi Chuan program increased their balance in single leg stance [35] and another intervention group had an improvement in scale for Activities-specific Balance Confidence [30].

In every study analyzed in this review, the exercise program implemented was safe for the participants without inducing or increasing risk of diabetic foot. Also, none of the controlled outcomes worsen at the end of the studies.

Furthermore, patients in exercise programs have demonstrated a better quality of life regarding physical, emotional and social domains [35].

However, there is still insufficient data regarding the best treatment approach for this patient population. There is a wide range of effective exercise interventions (Table 1) such as balance, strength-based, aerobic exercises or even a multi-modality treatment (exercise and education for foot care) that may help reduce or delay the risk of ulceration. The studies included in this review reported long-term $[31,32]$ and medium-term $[30,33,35,36]$ of exercise programs. In addition, the frequency of physical activity over time is also essential, i.e., patients who attended more in exercise weekly were more likely to be associated with successful results in accordance with international guidelines, however, some studies did not describe the intensity of the interventions $[30,31]$.

\subsection{Limitations}

A key limitation of this systematic review was the large heterogeneity of the instruments to measure diabetic foot related outcomes and this heterogeneity remained very broadly defined in the current literature, making it difficult to compare results. Another limitation is the lack of information about the intensity of the exercise programs in some studies [30,31]. Also, the lack of studies about this theme, involving physical activity or exercise in risk of ulceration within patients with diabetes are quite few in literature, so more studies are required.

\subsection{Recommendations for future research}

This systematic review combined the results of six trials, but more practice and methodologic work is needed to prove how physical activity and exercise can involve a better treatment for diabetic foot. An easy and homogeneous outcome to be easily accessed is required, intended to be effectively applied for non-clinical experts. An homogeneous outcome would facilitate the execution of meta-analyses.

\section{Conclusion}

This systematic review suggests physical activity and exercise as an efficient intervention to reduce the risk of diabetic foot. 
Although the variety of physical activity and exercise methods implemented in the trials, like aerobic exercise or combined modes of exercise, all have brought benefits in diabetic foot related outcomes.

Moreover, multi-disciplinary treatments, such as physical activity, diet routine and foot care education, all combined, are more effective in the improvement of diabetic foot outcomes than singular interventions.

\subsection{Practice recommendations}

Long-term physical activity and exercise is an effective tool to reduce risk of diabetic foot. Apart from the standard medical care, medication, diet and education for foot care, exercise is a potential additional intervention to reduce and control this clinical state.

Therefore, combined exercise programs with aerobic, resistance and balance exercises, can enhance the benefits of standard therapy.

\section{Summary}

Physical activity and exercise significantly improved nerve velocity conduction in the lower limbs, peripheral sensory function and foot peak pressure distribution.

Results of this study showed that a multi-disciplinary treatment, such as physical activity, diet routine and foot care education, all combined, are more effective in the improvement of diabetic foot outcomes.

The conclusion of this systematic review is that exercise is a beneficial non-pharmacological treatment, delaying the usual course of diabetic peripheral neuropathy, and delaying skin damage and ulceration.

\section{Contributorship}

MM, RM and NS planned the study. All authors contributed to the drafting of the manuscript, the development of the selection criteria, the risk of bias assessment strategy, and data extraction criteria. MM and NS developed the search strategy. All authors conducted the report screening, study inclusion, data extraction, and result interpretation and discussion.

\section{Funding}

This work was funded within the scope of project NANOSTIMA - Macro-to-Nano Human Sensing: Towards Integrated Multimodal Health Monitoring and Analytics from operation NORTE 010145 FEDER 000016, co-funded by the European Regional Development Fund [ERDF] through NORTE 2020 [Programa Operacional Regional do Norte 2014/2020].

\section{Conflicts of interest}

Monica Matos, Romeu Mendes, André Borges Silva and Nelson Sousa declare that they have no conflicts of interest relevant to the content of this review.

\section{Disclaimer}

The views expressed in the submitted article express solely the views of the contributing authors.

\section{Appendix A. Supplementary material}

Supplementary data associated with this article can be found, in the online version, at https://doi.org/10.1016/j.diabres.2018. 02.020 .

\section{R E F E R E N C E S}

[1] Amin N, Doupis J. Diabetic foot disease: from the evaluation of the "foot at risk" to the novel diabetic ulcer treatment modalities. World J Diabetes 2016;7:153-64.

[2] Reiber GE. The epidemiology of diabetic foot problems. Diabet Med 1996;13(Suppl 1):S6-S11.

[3] Gerassimidis T, Karkos CD, Karamanos D, Kamparoudis A. Current endovascular management of the ischaemic diabetic foot. Hippokratia 2008;12:67-73.

[4] Caputo GM, Cavanagh PR, Ulbrecht JS, Gibbons GW, Karchmer AW. Assessment and management of foot disease in patients with diabetes. N Engl J Med 1994;331:854-60.

[5] Frykberg RG, Armstrong DG, Giurini J, Edwards A, Kravette M, Kravitz S, et al. Diabetic foot disorders. A clinical practice guideline. For the American College of Foot and Ankle Surgeons and the American College of Foot and Ankle Orthopedics and Medicine. J Foot Ankle Surg. 2000;Suppl:160.

[6] McNeely MJ, Boyko EJ, Ahroni JH, Stensel VL, Reiber GE, Smith DG, et al. The independent contributions of diabetic neuropathy and vasculopathy in foot ulceration. How great are the risks? Diabetes Care 1995;18:216-9.

[7] Ndip A, Ebah L, Mbako A. Neuropathic diabetic foot ulcers evidence-to-practice. Int J Gen Med 2012;5:129-34.

[8] Alexiadou K, Doupis J. Management of diabetic foot ulcers. Diabetes Ther 2012;3:4.

[9] Wu SC, Driver VR, Wrobel JS, Armstrong DG. Foot ulcers in the diabetic patient, prevention and treatment. Vasc Health Risk Manage 2007;3:65-76.

[10] Jeffcoate WJ, Harding KG. Diabetic foot ulcers. Lancet 2003;361:1545-51.

[11] Pendsey SP. Understanding diabetic foot. Int J Diabetes Dev Countries 2010;30:75-9.

[12] Watkins PJ. The diabetic foot. BMJ 2003;326:977-9.

[13] Armstrong DG, Cohen K, Courric S, Bharara M, Marston W. Diabetic foot ulcers and vascular insufficiency: our population has changed, but our methods have not. J Diabetes Sci Technol 2011;5:1591-5.

[14] Zhang Z, Lv L, Guan S. Wound bed preparation for ischemic diabetic foot ulcer. Int J Clin Exp Med 2015;8:897-903.

[15] Mills JL. Lower limb ischaemia in patients with diabetic foot ulcers and gangrene: recognition, anatomic patterns and revascularization strategies. Diabetes Metab Res Rev 2016;32 (Suppl 1):239-45.

[16] Apelqvist J, Bakker K, Van Houtum WH, Nabuurs-Franssen $\mathrm{MH}$, Schaper NC. International consensus and practical guidelines on the management and the prevention of the diabetic foot. International Working Group on the Diabetic Foot. Diabetes Metab Res Rev 2000;16(Suppl 1):S84-92.

[17] Edmonds ME, Foster AV. Diabetic foot ulcers. BMJ 2006;332:407-10. 
[18] Dalla Paola L, Carone A, Vasilache L, Pattavina M. Overview on diabetic foot: a dangerous, but still orphan, disease. Eur Heart J Suppl 2015;17:A64-8.

[19] Walsh JW, Hoffstad OJ, Sullivan MO, Margolis DJ. Association of diabetic foot ulcer and death in a population-based cohort from the United Kingdom. Diabet Med 2016;33:1493-8.

[20] Chammas NK, Hill RL, Edmonds ME. Increased mortality in diabetic foot ulcer patients: the significance of ulcer type. J Diabetes Res 2016;2016:2879809.

[21] Jupiter DC, Thorud JC, Buckley CJ, Shibuya N. The impact of foot ulceration and amputation on mortality in diabetic patients. I: from ulceration to death, a systematic review. Int Wound J 2016;13:892-903.

[22] Rossaneis MA, Haddad MD, Mantovani MF, Marcon SS, Pissinati PS. Foot ulceration in patients with diabetes: a risk analysis. Brit J Nurs 2017;26:S6-S14.

[23] Sabapathy SR, Periasamy M. Healing ulcers and preventing their recurrences in the diabetic foot. Indian J Plast Surg 2016;49:302-13.

[24] Mendes R, Sousa N, Almeida A, Vilaca-Alves J, Reis VM, Neves EB. Thermography: a technique for assessing the risk of developing diabetic foot disorders. Postgrad Med J 2015;91:538.

[25] Armstrong DG, Lavery LA, Holtz-Neiderer K, Mohler MJ, Wendel CS, Nixon BP, et al. Variability in activity may precede diabetic foot ulceration. Diabetes Care 2004;27:1980-4.

[26] Boulton AJ. The diabetic foot: a global view. Diabetes Metabol Res Rev 2000;16: S2-S5.

[27] Colberg SR, Sigal RJ, Yardley JE, Riddell MC, Dunstan DW, Dempsey PC, et al. Physical activity/exercise and diabetes: a position statement of the american diabetes association. Diabetes Care 2016;39:2065-79.

[28] Mendes R, Sousa N, Reis VM, Themudo-Barata JL. Implementing low-cost, community-based exercise programs for middle-aged and older patients with Type 2 diabetes: what are the benefits for glycemic control and cardiovascular risk? Int J Environ Res Public Health 2017;14.

[29] Mueller MJ, Tuttle LJ, Lemaster JW, Strube MJ, McGill JB, Hastings MK, et al. Weight-bearing versus nonweight-bearing exercise for persons with diabetes and peripheral neuropathy: a randomized controlled trial. Arch Phys Med Rehabil 2013;94:829-38.

[30] Sartor CD, Hasue RH, Cacciari LP, Butugan MK, Watari R, Passaro AC, et al. Effects of strengthening, stretching and functional training on foot function in patients with diabetic neuropathy: results of a randomized controlled trial. BMC Musculoskelet Disord 2014;15:137.

[31] Lemaster JW, Mueller MJ, Reiber GE, Mehr DR, Madsen RW, Conn VS. Effect of weight-bearing activity on foot ulcer incidence in people with diabetic peripheral neuropathy: feet first randomized controlled trial. Phys Ther 2008;88:1385-98.

[32] Balducci S, Iacobellis G, Parisi L, Di Biase N, Calandriello E, Leonetti F, et al. Exercise training can modify the natural history of diabetic peripheral neuropathy. J Diabetes Complicat 2006;20:216-23.
[33] Dixit SM, Maiya AG, Shastry BA. Effect of aerobic exercise on peripheral nerve functions of population with diabetic peripheral neuropathy in type 2 diabetes: a single blind, parallel group randomized controlled trial. J Diabetes Complicat 2014;28:332-9.

[34] Maher CG, Sherrington C, Herbert RD, Moseley AM, Elkins M. Reliability of the PEDro scale for rating quality of randomized controlled trials. Phys Ther 2003;83:713-21.

[35] Ahn S, Song R. Effects of Tai Chi Exercise on glucose control, neuropathy scores, balance, and quality of life in patients with type 2 diabetes and neuropathy. J Altern Complement Med 2012;18:1172-8.

[36] Hung JW, Liou CW, Wang PW, Yeh SH, Lin LW, Lo SK, et al. Effect of 12-week tai chi chuan exercise on peripheral nerve modulation in patients with type 2 diabetes mellitus. J Rehabil Med 2009;41:924-9.

[37] Bahador RS, Afrazandeh, SS, Ghanbarzehi N, Ebrahimi M. The impact of three-month training programme on foot care and self-efficacy of patients with diabetic foot ulcers. J Clin Diagn Res. 2017;11:IC01-IC4.

[38] Charles M, Soedamah-Muthu SS, Tesfaye S, Fuller JH, Arezzo JC, Chaturvedi N, et al. Low peripheral nerve conduction velocities and amplitudes are strongly related to diabetic microvascular complications in type 1 diabetes: the EURODIAB prospective complications study. Diabetes Care 2010;33:2648-53.

[39] Kong X, Lesser EA, Potts FA, Gozani SN. Utilization of nerve conduction studies for the diagnosis of polyneuropathy in patients with diabetes: a retrospective analysis of a large patient series. J Diabetes Sci Technol 2008;2:268-74.

[40] Said G. Diabetic neuropathy-a review. Nat Clin Pract Neurol 2007;3:331-40.

[41] Kobori M, Yagihashi S, Shiina N, Shiozawa N, Haginoya A, Ojima M, et al. Four-year sequential nerve conduction changes since first visit in Japanese patients with early type 2 diabetes. J Diabetes Investig 2017;8:369-76.

[42] Colberg SR, Sigal RJ, Fernhall B, Regensteiner JG, Blissmer BJ, Rubin RR, et al. Exercise and type 2 diabetes: the American College of Sports Medicine and the American Diabetes Association: joint position statement executive summary. Diabetes Care 2010;33:e147-67.

[43] Tuomilehto J, Lindstrom J, Eriksson JG, Valle TT, Hamalainen H, Ilanne-Parikka P, et al. Prevention of type 2 diabetes mellitus by changes in lifestyle among subjects with impaired glucose tolerance. N Engl J Med 2001;344:1343-50.

[44] Sigal RJ, Kenny GP, Wasserman DH, Castaneda-Sceppa C, White RD. Physical activity/exercise and type 2 diabetes: a consensus statement from the American Diabetes Association. Diabetes Care 2006;29:1433-8.

[45] Inzucchi SE, Bergenstal RM, Buse JB, Diamant M, Ferrannini E, Nauck M, et al. Management of hyperglycemia in type 2 diabetes, 2015: a patient-centered approach: update to a position statement of the American Diabetes Association and the European Association for the Study of Diabetes. Diabetes Care 2015;38:140-9. 